\title{
A pregação no Brasil colonial ${ }^{\star}$
}

\author{
Preaching in colonial Brazil
}

\author{
MARINA MASSIMI \\ Faculdade de Filosofia Ciências e Letras \\ Universidade de São Paulo - campus de Ribeirão Preto \\ Av. Bandeirantes, 3900 \\ Ribeirão Preto - SP - Brasil - 14040-901 \\ mmassimi@terra.com.br
}

RESUMO O estudo da oratória sagrada no Brasil do período colonial é um campo heurístico de grande interesse para a história cultural, sendo que os sermões constituíram-se numa importantíssima fonte de transmissão de doutrinas e de modelagem dos comportamentos numa sociedade onde a oralidade era a modalidade principal de difusão dos conhecimentos. O percurso traçado no artigo aponta para evidências claras da importância, da freqüência e do grande alcance das atividades da pregação no contexto do Brasil do século XVI ao século XVIII. Esclarece também as funções assumidas por estas atividades: a catequese, a doutrinação dos ouvintes, a reforma dos costumes abrangente toda a realidade pessoal, social e política dos emissores e dos destinatários.

Palavras-chave História religiosa luso-brasileira; pregação, Hstória cultural

ABSTRACT The study of sacred oratory in colonial Brazil is a heuristic field of great interest to cultural history, being that sermons were a very

Artigo recebido em 13/11/2004; Aprovado em 15/02/2005. 
important source of doctrine transmission and of behavior modeling in a society in which speech was the main mode of knowledge diffusion. The course traced in this article points to clear evidence of the importance, frequency, and the broad scope of preaching activities in the context of Brazil in the $16^{\text {th }}$ to $17^{\text {th }}$ century. The article also enlightens the functions taken by these activities: catechism, indoctrination of the listeners, and the reform of customs that approached the personal, social, and political reality of emitters and receivers.

Key words luso-brazilian religious history; preaching, cultural history

\section{Origens das atividades de Pregação no Brasil colonial}

A pregação no contexto da sociedade brasileira colonial era uma atividade difusa e bastante valorizada pela população. Notícias e descrições acerca das atividades de pregação são freqüentes em relatos e cartas de viajantes e missionários, desde os primeiros tempos da colonização. Uma das informações mais antigas a respeito, é fornecida por uma narrativa de 1593 do padre visitador da Companhia de Jesus, o português Fernão Cardim (1548-1625): curiosamente, porém, refere-se não à pregação dos missionários e sim às atividades de pregação dos próprios índios em ocorrência da visita pastoral dos padres missionários. ${ }^{1} \mathrm{O}$ relato merece ser analisado, por destacar as peculiaridades da retórica indígena e frisar a grande propensão dos nativos para a prática da palavra. Inclusive, evidencia como a pregação dos "principais" indígenas foi necessária para criar a confiança de suas tribos na palavra pregada pelos jesuítas. ${ }^{2}$

Talvez seja esta familiaridade das populações com o uso do discurso para persuadir e ensinar, um dos motivos da relevância atribuída pelos missionários à pregação como meio de cristianização das populações brasileiras. Cardim relata que, na aldeia do Espírito Santo, após serem recebidos pelos "principais", ${ }^{3}$ os padres visitadores Fernão Cardim, Cristóvão de Gouveia e o irmão Barnabé Telho, foram levados em procissão à Igreja pelos índios com danças e músicas de flautas. Citamos o relato mantendo seu estilo e escrita originária:

1 CARDIM, F. Tratado da Terra e Gente do Brasil. Edição moderna organizada por Garcia, R. São Paulo/Belo Horizonte: Editora da Universidade de São Paulo/ Editora Itatiaia, 1980. Coleção Reconquista do Brasil, n. 13. (Original: 1593).

2 Vários documentos atestam este fato, por exemplo, a carta enviada por José de Anchieta à Laínez, de São Vicente, no dia 8 de janeiro de 1565. Em: ANCHIETA, J. Cartas, framentos históricos e Sermões, Cartas Jesuíticas, n. 3, São Paulo/Belo Horizonte: Editora da Universidade de São Paulo/Itatiaia, 1988, p.133-134. Coleção Reconquista do Brasil, n.149.

3 Expressão utilizada nos relatos missionários da época para indicar as autoridades políticas das populações nativas. 
Feita a oração, Ihes mandou o padre fazer uma falla na língua, de que ficaram muito consolados e satisfeitos; aquela noite os índios principais, grandes línguas, pregavam da vida do padre a seu modo, que é da maneira seguinte: começam a pregar de madrugada deitados na rede por espaço de meia hora, depois se levantam, e correm toda a âldea, pé ante pé muito devagar, e o pregar também é pausado, freimatico, e vagaroso; repetem muitas vezes as palavras por gravidade, contam nestas pregações todos os trabalhos, tempestades, perigos de morte que o padre padeceria, vindo de tão longe para os visitar, e consolar, e juntamente os iniciam a louvar a Deus pela mercê recebida, e que tragam seus presentes ao padre, em agradecimento. Era para os ver vir com suas cousas, etc., patos, galinhas, leitões, farinha, beijús com algumas raízes e legumes da terra (Cardim, 1980, p. 146).

Os chefes da tribo, apropriando-se do discurso do missionário pregador, traduzem-no em sua própria linguagem para transmiti-la à comunidade, legitimando assim a presença do padre e, ao mesmo tempo, colocando-se como mediadores insubstituíveis entre este e o povo.

No mesmo documento, Cardim fornece outras informações acerca do valor da pregação junto aos índios, ao descrever as ocas indígenas e sua organização social. Com efeito, em cada "oca" mora um principal, cuja autoridade exerce-se principalmente pelo uso da palavra:

Este exhorta a fazer suas roças e mais serviços, etc., excita-os à guerra; e lhe têm em tudo respeito; faz-Ihes estas exhortações por modo de prégação, começa de madrugada deitado na rede por espaço de meia hora, em amanhecendo se levanta, e corre toda a âldea continuando sua prégação, a qual faz em voz alta, mui pausada, repetindo muitas vezes as palavras. Entre estes seus principaes ou prégadores, há alguns velhos antigos de grande nome e autoridade entre elles, que têm fama por todo o sertão, trezentas e quatrocentas léguas, e mais. Estimam tanto um bom língua que Ihe chamam o senhor da fala. Em sua mão tem a morte e a vida, e os levará por onde quiser sem contradição. Quando querem experimentar um e saber se é grande língua, ajuntamse muitos para ver se o podem cansar, falando toda noite em peso com ele, e ás vezes dois, três dias, sem se enfadarem. Estes principais, quando o padre visitador chegava, prégavam a seu modo dos trabalhos que o padre padeceu no caminho, passando as ondas do mar, e vindo de tão longe, exposto a tantos perigos para os consolar, incitando a todos que se alegrassem com tanto bem, e lhe trouxessem suas cousas (idem, pp. 152-53).

A descrição de Cardim deixa transparecer o maravilhamento do religioso português diante da importância atribuída ao uso da palavra pelos índios brasileiros: inesperado ponto de convergência entre a cultura desconhecida destas populações e o esforço de comunicação da cultura européia daquela época, evidente na criação de novos instrumentos como a imprensa, pela busca de contatos e conhecimentos de novos povos, novas culturas e novas línguas, pelo grande desenvolvimento da arte retórica e das suas infinitas possibilidades enquanto meio pedagógico e doutrinário. 
Em sua narrativa, Cardim refere-se também à pregações feitas pelos jesuítas na Terra de Santa Cruz, junto às ermidas de senhores de engenhos e à presença de um padre que conhecendo a "língua da Guiné" fazia práticas aos escravos africanos (idem, p. 167). Cita Padre Quírico Caxa, Padre Manuel de Castro e Padre Manuel de Barros, como os meIhores pregadores da Província e afirma que dos sermões tirava-se grande proveito para a evangelização do povo (idem, p. 158). Lembra que, ao longo da estádia no colégio de Pernambuco, assistiu à pregação de Padre Luís da Grã, o qual "tem muito bom púlpito e as boas cousas e graça em as propor, e assim nesta como nas mais cousas é mui aceito e amado de todos da terra" (idem, p. 163). Análogas atividades de pregação são relatadas em muitas outras etapas da visita narrada por Cardim.

A função da palavra do sermão dirigido aos indígenas, no que diz respeito à estimulação dos afetos e à mudança dos costumes, é evidenciada também pelo capuchinho francês Cl. D'Abbeville, autor de um relato acerca da missão desses religiosos nas terras do Maranhão, da qual ele mesmo participou, em 1614: "Com tal atenção ouviram os índios essas palavras que a emoção que Ihes ia na alma transparecia em suas fisionomias." (1975, p. 72)

Que o influxo da pregação na formação da mentalidade pessoal e social permaneça ao longo do tempo, é demonstrado por um trecho encontrando no Arquivo Público Mineiro num documento de 1899, ${ }^{4}$ onde um escritor mineiro de Jacuhy, referindo-se ao lamentável estado atual da cidade, pergunta-se, referindo-se à pregação por lá ministrada nos tempos passados pelo capuchinho italiano frei Francisco de Ravena: "Seria a realização da prophecia de um missionário que há annos alli esteve e que em um sermão, prophetisou a Jacuhy um futuro de desgraças?" (p. 240). A importância da pregação na mentalidade e na cultura brasileira aparece aqui em toda a sua evidência: a palavra do pregador possui uma eficácia tal que é capaz de manifestar seus efeitos concretos ao longo de muito tempo. E, ainda referido à pregação na região de Minas, mas no século precedente, encontra-se o importante testemunho de Nuno Marques Pereira, ${ }^{5}$ o qual em sua narrativa relata as atividades de pregação realizadas naquele território, ao longo do século XVIII, e especialmente no capítulo decimo sexto do segundo livro do Compêndio Narrativo do Peregrino de América chegando a "reproduzir" em sua narrativa o texto de um sermão e descrevendo em pormenores os efeitos da pregação na consciência individual e nos comportamentos sociais dos protagonistas.

4 Na Revista do Arquivo Público Mineiro, n.IV, 1989, Fasc. 3 e 4, em PAULA SOUZA, F. Reminiscências da comarca de Jacuy, 1899, p.237 a 262.

5 PEREIRA, Nuno Marques. Compendio Narrativo Do Peregrino De América. 6a.ed. Rio de Janeiro: Academia Brasileira, 1939. 2v. 


\section{A normatização da pregação pela Igreja católica no Brasil}

Devido à grande importância e eficácia da pregação junto à população, fez-se necessário, ao longo do tempo, ordena-las a seus objetivos prioritários e controlar seus artífices, através de uma legislação específica. O próprio conteúdo das normas revela os possíveis descaminhos do uso da oratória sagrada, provavelmente ocorridos com uma certa freqüência. Com efeito, a normatização da pregação no Brasil segundo os ditames do Concílio de Trento encontra-se nas Primeiras Constituições do Arcebispado da Bahia de 1707. Na edição das Constituições ${ }^{6}$ de 1720, procura-se colocar limites no que diz respeito à demanda do sermão no âmbito das celebrações litúrgicas das exéquias. ${ }^{7}$ Além do mais, as Constituições estabelecem a necessidade de avaliar o preparo dos pregadores, diante dos freqüentes abusos registrados. ${ }^{8}$ A necessidade de centralizar a realização dos exames para concessão aos interessados das licenças (em forma de documento escrito) para proferir sermões junto a um órgão competente, justifica a norma decretada pelo Arcebispo de Salvador,"em que se prohibe aos Pregadores pregar sem licença nossa nesse nosso Arcebispado". (Art. 513, Titulo 21, Liv. 3: p. 207). A mesma normativa proíbe também de receber pregadores sem licença aos párocos e aos superiores dos conventos religiosos. ${ }^{9}$

Quais sejam as condições requeridas para a concessão da licença de pregar é estabelecido no artigo 516 das referidas Constituições: ${ }^{10}$ boa formação cultural, vida e costumes exemplares, idade apropriada e

6 Das Constituições Primeyras Do Arcebispado Da Bahia Feytas E Ordenadas Pelo Illustrissimo E Reverendisismo Senhor D. Sebastião Monteyro Da Vide, Arcebispo Do Dito Arcebispado E Do Concelho De Sua Magestade, Em O Synodo Diocesano Que O Dito Senhor Celebrou Em 12 De Junho De 1707. Coimbra: Real Colégio das Artes da Companhia de Jesus, 1720.

7 Por muyto justas razones se prohibem exéquias que mais parecem excessos de vaidade humana, do que effeytos da Religião Christã. Pôr tanto mandamos, que se não fação nas Igrejas essas ou tumbas, nem armem as Igrejas ou Capellas nem haja Sermão, Oração, ou Pratica nas taes exéquias, exceto nas do Summo Pontífice, Reys deste Reyno e Prelados, sem licença nossa a qual ano daremos sem muyta consideração do estado, e qualidade do defunto. (Idem, Art. 840, Liv.4, Titulo 52, p.314).

8 Art. 512. Da Pregação E Pregadores: "Por quanto a pregação da palavra de Deos nosso Senhor he o mantimento espiritual das almas, e muyto necessária para a salvação dellas, como diz o Sagrado concilio Tridentino, se encarrega muyto aos Prelados pelo mesmo Concilio esta obrigação e se chama no direyto Canônico officio seu próprio. (....) Pelo que em execução destes decretos, e de nossa obrigação pastoral, encomendamos muyto a todos os Senhores Arcebispos nossos sucessores que quando por si próprios puderem, preguem a Palavra de Deos nosso Senhor, e para o tempo e lugares em que nao puderem fazer, escolhão homens doutos, e versados nas Divinas letras, lições dos Santos e de boa virtude, e costumes para Pregadores desse Arcebispado, e no conceder das licenças, se hajão com grande exame, como se requer para o tal officio (Idem. p.207 e ss).

9 Os Regulares e Religiosos de qualquer Ordem que sejão, não poderão pregar ainda nas Igreja de suas Ordens, sem terem aprovação de seus superiores, e sem serem examinados por elles na sciencia, e terem especial licença sua, (...) e sem ella não poderão pregar" (Idem, Art. 515, p.209).

10 Procurando Nós e desejando muyto que os Pregadores, que neste nosso Arcebispado houverem de pregar, tenhão as letras, vida e costumes que se requer, mandamos que para se lhes passar licença sejão primeyro examinados de sciencia por Nós, ou nosso Provisor, ou pelas pessoas as quaes o cometermos, e achandoos idôneos, tendo Ordens Sacras e havendo boa informação de sua vida, e costumes, e de que têm idade competente, Ihe mandaremos passar licença pelo tempo, e lugares que nos parecer. E antes de começar a pregar farão o juramento de Profissão de Fé como se manda no motu proprio do Papa Pio IV, na forma que fica dito no livro 1, n.12. (idem, p. 109). 
posse das Ordens Sagradas, além de uma boa proficiência no exame apropriado realizado pela autoridade indicada, são os elementos que permitem a concessão da idoneidade ao pregador. Portanto, todos os pregadores atuantes no território submetido à jurisdição do Arcebispado da Bahia, podiam proferir sermões por terem sido reconhecidos dignos de ser os intérpretes e os transmissores da ortodoxia cristã.

As Constituições estabelecem normas não apenas no que diz respeito às modalidades da pregação, mas também aos seus conteúdos. No Titulo 22 do Livro 2, por exemplo, impõe-se aos pregadores que declarem aos ouvintes a obrigação que têm enquanto participes da comunidade eclesial, ao pagamento do dizimo. O pregador deve deter-se na admoestação no que diz respeito aos "Novíssimos Do Homem", assim definidos no artículo 571 das Constituições: "Os Novíssimos do homem são quatro. O primeyro he Morte. O segundo, Juízo. O terceyro, Inferno. O quarto, Paraíso" (idem, p. 227). E o artigo n. 417 do mesmo livro, afirma que

E porque o direyto obriga, sob pena de peccado mortal aos Pregadores que exhortem e persuadão nos sermões que fizerem no primeiro, quarto e ultimo domingo de Quaresma, e nas festas da Ascenção de Christo, Pentecostes, Assumpção e Nascimento da Virgem nossa Senhora, nas domingas de outubro (idem, p. 174-75).

Para "exortar e persuadir" nesta ocorrências especiais marcadas no calendário litúrgico ${ }^{11}$, será necessário que as palavras do sermão atingiam as três "potências da alma": memória, entendimento e vontade, ${ }^{12}$ pela via dos "sentidos corporais". ${ }^{13}$

Esta normatização estende-se, ao longo do século XVIII, pelo inteiro território nacional. Relatamos um exemplo. No Arquivo da Cúria de Mariana encontramos documentos que atestam a aplicação rigorosa da legislação das Constituições, por obra do bispo de Rio de Janeiro, São Paulo e Minas Gerais, frei Antônio de Guadalupe e dos primeiros bispos da Diocese de Mariana, entre outros do frei Manuel da Cruz. ${ }^{14}$ Antes

11 Á pertinência de cada período do tempo liturgico para abordar aspectos específicos da experiência humana e do caminho cristão da conversão, será dedicado o capítulo quinto.

12 As potências d'alma são três. (Tractado Jardim espiritual, 5 e 8). A primeira he a Memoria. A segunda, o entendimento. A terceira a Vontade (Artículo n. 568, p.227) .

13 No artículo n. 570, são definidos os "sentidos corporais": "Os sentidos corporaes são cinco. O primeyro he o ver. O segundo, ouvir. O terceyro cheyrar. O quarto, gostar. O quinto, apalpar. (p.227).

14 Com efeito, assim declara a Primeira Pastoral escrita e publicada em Minas Gerais, na Vila de São João del Rey, aos 3 de novembro de 1727, por S. Dom Frei Antônio de Guadalupe, Bispo do Rio de Janeiro, São Paulo e Minas Gerais: "Os sacerdotes a quem damos licença para pregar, é com a obrigação de pregarem a doutrina sólida ainda nas festividades, pelo que Mandamos aos Párocos que depois da Páscoa de cada ano Nos dê conta dos pregadores que pregaram nas suas Igrejas declarando se pregaram ou não doutrina, para sabermos se thes Havemos de confirmar ou não a licença e no mesmo tempo nos darão conta do estado de suas Igrejas, digo, Freguesias e no progresso que nelas ha no serviço de Deus e os que faltarem a isto, os Havemos por suspensos o tempo que nos parecer. Com a mesma pena de suspensão ipso facto Mandamos que nenhum Pároco ou Capelão, ainda que seja de pessoa particular, consinta que nas Sacristias e Capelas 
disto, em 1730, o bispo frei João da Cruz, na ocasião de sua Visita Apostólica e Pastoral em São Caetano e Ribeiro do Carmo, redigira uma Carta Pastoral onde definiam-se os objetivos da pregação:

E avisamos a todos os Pregadores que sirvam a sua condição não só de callificarem as suas letras nas pregações mas para advertirem aos seus ouvintes o perigo com que caminhão por este mundo e para ponderarem quanto deve ser estimada por todos a salvação a que devemos aspirar, reprehendendo sempre os vicios, como verdadeiramente devem ser os sermões. ${ }^{15}$

O objetivo do sermão, portanto, não deve ser mostrar a erudição do pregador, mas exortar os ouvintes à conversão das almas e à reforma das condutas.

O Relatório Do Episcopado De Mariana Para A Sagrada Congregação Do Concílio De Trento, ${ }^{16}$ elaborado por Frei Manuel Da Cruz ${ }^{17}$ aos 1 de Julho de 1754 — onde o bispo descreve ao Sumo Pontífice a situação da Igreja Marianense — afirma que é obrigação dos párocos "pregar ao povo nos domingos e festas solenes". ${ }^{18}$ Nesse relatório, o bispo descreve pormenorizadamente a situação de sua diocese: ${ }^{19}$ Frei Manuel narra ter chegado em Mariana, vindo do Maranhão, em 1748 e que, logo após sua instalação, decidiu fundar o seminário, para a formação dos padres e educação dos meninos. ${ }^{20}$ Afirma de ter estabelecido sua residência permanente em Mariana, realizando visitas em toda a diocese e de ter, nessas ocasiões, assumido também a função de pregador. Com efeito, a aplicação das normas acerca da pregação indicadas pelas Constituições, exige a presença e o exemplo das autoridades eclesiásticas neste campo. Não se trata apenas de estabelecer normativas e sim de fornecer modelos a serem imitados, para que esta função tão importante na cristandade, seja exercida de modo digno e eficaz.

preguem, ouçam confissões, ou digam missas sacerdotes alguns secular ou regular, se ele não mostrar licença in scriptis Nossa, ou de nosso Provisor, da qual suspensão Reservamos Nós a absolvição". (f.4,5) .

15 Rio de Janeiro, 18 de maio de 1741 João da Cruz, Pastoral para todo o bispado, fl.21 e 22, Copia de uma pastoral que o excelentíssimo e reverendíssimo Senhor Dom frei João da Cruz mandou publicar.

16 Este relatório substitui a visita ad limina em Roma junto ao Sumo Pontífice, decenal, que tinha sido instituída pelo Concílio de Trento.

17 Um documento transcrito na Revista do Arquivo Público Mineiro, refere-se a criação da diocese de Mariana em 23 de abril de 1745 e a entrada triunfal do bispo: "publica entrada cuja celebridade de executou com a especialissima pompa, que refere a história desta criação intitulada Áureo Trono episcopal, colocado nas minas de ouro, autor anônimo". (Documento n. 10 Informação das antigüidades da cidade de Mariana p.248 a $255, \mathrm{fl} .67 \mathrm{v}-74 \mathrm{v}, \mathrm{fl} .72$ ).

18 "Compete, pois, aos referidos Capelães, pregar ao Povo nos Domingos e Festas solenes, dedicar-se assiduamente em explicar o Catecismo à gente simples, fazer a Oração Mental, recordar os Mistérios da Paixão do Senhor e recitar devotadamente com os mesmos fieis as saudações do Rosário Mariano e Angélico. Através de edito Pastoral, prescrevi se cumprissem todos esses ritos de devoções exatamente do mesmo modo como devem ser feitos em cada paróquia" (Idem, p.1).

19 Relatório Do Episcopado De Mariana Para A Sagrada Congregação Do Concílio De Trento. Autor: Frei Manuel Da Cruz, Mariana, 1 De Julho De 1754. Cópia Do Original Que Se Encontra Em Roma Arquivo Vaticano, S.Congregação. Concilii N.489, Mariannem In Brasilia, Tradução.

20 Pois, nele admitiam-se alunos internos e externos. Trata-se da única escola pública em toda a diocese. Estuda-se nela oito anos de gramática e teologia moral e filosofia. 
Manuel da Cruz era cisterciense, mestre em Sagrada Teologia e Doutor pela Universidade de Coimbra. Fora bispo no Maranhão e naquela ocasião companheiro de missão e grande admirador dos Padres da Companhia de Jesus. Portanto, uma vez na diocese de Mariana, sob a influência dos jesuítas, introduzira a prática espiritual da "oração mental", visando estimular a elaboração pessoal do conteúdo doutrinário ouvido pela pregação. ${ }^{21} \mathrm{O}$ fato de que a pregação seja um meio eficaz de uma urgente reforma dos comportamento transparece nas entrelinhas do referido relatório, quando o autor descreve com preocupação a situação moral e religiosa dos moradores: "O território desta região aurífera, a nenhum outro inferior na incontável multidão de habitantes e adventícios, sobrepuja as maiores cidades do Orbe na torpeza diversificada dos vícios". (idem, p. 6)

Seu sucessor no trono episcopal, Dom Frei Domingos da Encarnação Pontevel da Ordem dos Pregadores, na crônica da visita pastoral na Capela de Nossa Senhora da Piedade da Espera na freguesia de Itaverava realizada em 18 de setembro de 1781,22 reitera com clareza a necessidade de regulamentar e controlar as atividades dos pregadores na diocese. Especifica que,

Que todos os Pregadores (officio que não poderão exercitar sem especial approvação nossa e licença ainda que sejão Parochos) devem pregar sempre e ainda mesmo nos Panegyricos, Doutrina solida e Evangelica em toda a sua nativa pureza, e simplicidade sem a profanarem com vans, e estereis apparatos de humana Política e eloquencia, a qual servindo apenas de lisongear aos mundanos, e de recriar-Ihes os ouvidos, já mais possa prover-Ihes festivamente os coraçõens, devendo todos os reverendos parochos passar-nos annualmente certidam jurada de que assim o cumprem, os que tem pregado nas suas freguesias, ajuntando também estas com as mais attestaçoens geraes que lhes ordenamos, a que nos devem sem falta annualmente remetter (idem, p. 433).

\section{A formação dos pregadores na colônia ${ }^{23}$}

A preocupação com a boa formação dos sacerdotes e pregadores ${ }^{24}$ evidenciada pelo documento acima citado, concretiza-se na instituição

21 Na Pastoral de Frei Manuel da Cruz, Mariana, 1748 (encontrada no Arquivo da Cúria de Mariana, pasta n. 6 armário 1 gaveta 1), no Capítulo 5, folha 14, se introduz a prática da oração mental: "Como a oração mental é o meio mais útil e convincente para a salvação das almas, em atenção da qual o nosso S.S..Padre Benedicto XII expedio a Bulla em a qual concede muitas e grandes Indulgencias a quem a exercitar, aprender, ou ensignar, como na mesma Bulla declara, mandamos ao Reverendo Cura faça aos seos Fregueses a oração mental na forma do Directorio que Ihes deixamos para ella".

22 Na Revista do Arquivo Público Mineiro, n. VII, Fasc.1-2, 1902, p.427 a 436.

23 Neste artigo, forneceremos apenas uma descrição sucinta dos conteúdos desta formação, sendo que para um aprofundamento do tema remetemos a outro artigo nosso: "A palavra sagrada no Brasil da Idade Moderna", Coletânea, Rio de Janeiro, 2004 (no prelo).

24 Entre os documentos do bispo frei Domingos da Encarnação Pontevél, encontramos em seu testamento, a lista de livros da sua Biblioteca, tendo informações importantíssimos acerca dos textos de oratória sagrada nela contidos (Frei Domingos Da Encarnação Pontenevel Bispo De Mariana Entre 1779 A 1793. Pasta 11 Gav. 4, 1793. Lista de livros). Na Lista constam 27 obras de oratória sagrada. 
do Seminário Episcopal de Mariana. Nestes termos, Pontenevel referese à criação da escola pelo seu predecessor Manuel da Cruz:

Estabeleceu o mesmo Prelado dentro da cidade um seminário de estudos de Gramática e Moral, adquirindo para a dita casa muitas esmolas, legados a doações, (...) regido pelo reverendo padre José Nogueir ${ }^{25}$ da Companhia de Jesus, que veio do Colégio de Rio de Janeiro para reitor e mestre da dita casa. Freqüentam as classes muitos estudantes com os mesmos estatutos dos colégios da Companhia, espera-se que Sua Magestade facultará o residirem mais mestres da mesma Companhia. Abriram-se aqueles estudos no ano de 1748. (f.72v).

Os acontecimentos da história política e religiosa de Portugal e da Colônia em meados do século XVIII — que levaram à expulsão dos Jesuítas do território luso-brasileiro, e posteriormente à extinção da Ordem inviabilizarão este projeto de colaboração entre o seminário e a Companhia de Jesus, no que diz respeito à formação. De qualquer forma, o cuidado com o preparo dos pregadores é ainda hoje amplamente documentado pelos livros adquiridos para auxiliar os estudos e que ainda hoje podem ser achados em Mariana, no Museu da Casa dos Bispos. Na Biblioteca, que pertencia ao Seminário, existe farta bibliografia sobre pregação. A partir desta pode-se reconstruir a "biblioteca ideal" para a formação de um pregador, no Brasil colonial: contém por volta de 100 obras de referência da oratória sagrada, em vários idiomas (latim, português, italiano, espanhol, francês) inclusive a obra completa de Granada, uma Bibliotheca Concionatoris, e as obras do famoso pregador jesuíta italiano Paulo Segneri. ${ }^{26}$

Um autor na área cujas obras aparecem com freqüência seja na referida Biblioteca seja nas citações de vários pregadores é Luís de Granada. O seu tratado de Los seis libros de la Retorica Eclesiastica o dela Manera de Predicar, ${ }^{27}$ dedicada aos estudantes da Universidade de Évora, que visa "tornar seus alunos, insignes pregadores de Cristo", apoiase em Agostinho ${ }^{28}$ e Cícero, ${ }^{29}$ para fortalecer a afirmação de que "a arte do bem falar deve ser aprendida na juventude" e será assimilada com tanta maior facilidade "quanto mais os alunos estiverem imbuídos pelas

25 José Nogueira, nascido em Recife, entrou na Companhia de Jesus, onde foi professor de Letras, Humanidades e teologia e superior do seminário de Mariana e deportado pelo Pombal, Leite S., História da Colonização do Brasil, tomo 9, p.14, vol. 1, p.51.

26 A consideração das obras de oratória sagrada contidas neste acervo merece um estudo à parte.

27 In: GRANADA, L. Ecclesiasticae Rhetoricae sive de ratione concionandi libri sex, Venezia: Ziletti, 1578.

O livro foi escrito em língua latina e posteriormente traduzido para o espanhol. Utilizamos a edição espanhola: GRANADA, L. Los seis libros de la Retorica Eclesiastica o de la manera de predicar. ARIBAU, B.C. (org) Biblioteca de autores espanoles. Obras de fray Luís de Granada, tomo 3, Madri: Real Academia espanola, 1945, p.488-642.

28 AGOSTINHO, A. Doutrina cristã. São Paulo: Edições Paulinas, 1991, lib.4, cap. 3.

29 CÍCERO, M.T. De l'Orateur. Paris: Les Belles Lettres, 1927. lib.1, cap.3. 
ciências dialéticas e filosóficas". (ibidem). Por isto, justifica a necessidade de recorrer ao estudo da arte retórica, visando "a finalidade que o ensino desta arte, assim como as demais, serve também à teologia sagrada e ao ministério da palavra divina".

Outro autor importante na formação dos métodos retóricos missionários no contexto brasileiro é o jesuíta português Cipriano Soares. Inácio de Loyola, nutrido por uma solida cultura clássica, proclamara diretrizes que previam a leitura direta dos grandes textos da retórica clássica, alinhavada segundo os cânones da cultura humanista. Conforme esta orientação, o pequeno manual de retórica elaborado por Soares, ${ }^{30}$ De arte rhetorica libri tres, impresso em Coimbra em 1560 e oficialmente adotado nas escolas da Companhia, é uma espécie de resumo de passos derivados de Aristóteles, Cícero, e Quintilião. Devido ao seu caráter sintético, teve centenas de reedições, alcançando uma difusão européia (consta, por exemplo, nos currículos de colégios jesuítas italianos, portugueses, espanhóis, flamengos, alemães). ${ }^{31} \mathrm{O}$ compêndio que devia ser decorado - conforme preceitos da Ratio Studiorum - baseia-se no método da imitação, sendo que o ensino da retórica é realizado em chave pedagógica: não se trata de técnica em quanto tal, mas de um recurso formativo no qual a palavra é concebida com sua plena potencialidade de comunicação, baseando-se na concepção ciceroniana de Cícero da língua enquanto forma transmitida em que é custodiado o conteúdo da civilização herdado.

Na Biblioteca do Hospício da Terra Santa em Sabará, existente desde 1712 - enquanto residência do clero com o nome de "Capelinha do Hospício" erguida em evocação a Nossa Senhora do Pilar"32 e atualmente conservada junto ao Arquivo Casa Borba Gato de Sabará, encontramse vários volumes de oratória sagrada do século XVIII. Ainda em Minas Gerais, na cidade de São João del Rey, no acervo da atual Universidade Federal, que preserva antigos acervos particulares e municipais da cidade, existem significativas obras de oratória sagrada que possivelmente pertenceram a coleções particulares de sacerdotes e pregadores, dentre as quais destacamos: as obras de Manoel Bernardes da Congregação do Oratório: Exercícios Espirituais (1759 e 1784), Nova Floresta

30 SOARES, C. De arte retorica libri III, ex Aristotele, Cicerone et Quintiliano precipue deprompti, nunc ab eodem recogniti et multis in locis locupletis. Roma: F. Zanettum, 1580.

31 O texto documenta o trabalho de assimilação da cultura humanista realizado pela filosofia escolástica do século XVI, realizado em Salamanca e em Coimbra, trabalho do qual os manuais do Curso Conimbricence, representam uma das expressões mais significativas. Destes, Soares compartilha o método de análise crítica dos textos e a comparação entre as fontes antigas e a tradição bíblico-patrística. $\mathrm{O}$ empenho em unir a retórica clássica com a eloquência cristã, é um exemplo da intenção de conciliar fé e razão, antigos e modernos.

32 Descrita por AVILA. A. Barroco, Belo Horizonte/UFMG, n..8, 1976, p.49; e por TETEROO, Samuel Frei. Subsídios para a Historia da Ordem Terceira de São Francisco em Minas, Revista Eclesiastica Brasileira, 1946, 6829,351 
(1759), Luz E Calor, Obra Espiritual Em Que Se Tratão Dos Exercicios Da Virtude E Caminho Da Perfeição, (Lisboa, 1724); de Luís de Granada, Guia Dos Pecadores, (1794); o tratado de autor anônimo Conversações Familiares, (1762); a obra de Luís Verney, Novo Método, (1751); de Theodoro De Almeida, O Feliz Independente De Tudo, (1779). ${ }^{33}$

Em meados do século XVIII, no contexto luso-brasileiro, fazem-se presentes também as influências da mentalidade secularizada e iluminista incipiente, na concepção da formação dos pregadores e do estilo de pregar. Estas podem ser reconhecidas na leitura de uma obra difusa nas bibliotecas eclesiásticas da época, as Conversações Familiares, ${ }^{34}$ livro destinado ao uso dos pregadores sobretudo principiantes, indicando para eles "a sciencia que devem ter, o methodo que devem seguir, o estylo a que devem aspirar". A critica à tradição da oratória sagrada, que atinge também o próprio príncipe da retórica luso-brasileira, Antônio Vieira, é a de que as agudezas de sua erudição atingem a imaginação dos ouvintes mas não as demais faculdades intelectuais, capazes de mover a vontade e os afetos e desse modo propiciar a reforma dos costumes. ${ }^{35}$ Retomando uma dica platônica de que a retórica deve ser baseada na ciência do homem individual e em sociedade, o autor afirma que o processo de formação do pregador deve torna-lo capaz de "conhecer quae sejão os interesses dos homens, suas paixões, suas desordens", e "saber indagar os meios, pelos quaes se costumam refrear os excessos das paixões, a maneira de as regular, e de que modo se poderão dirigir ao bem, para que o homem possa viver em paz e conservar a sociedade entre os outros homens" (p. 121). ${ }^{36}$ Reprova também o recurso à imitação dos exemplos famosos pregadores: cada um deve compor a pregação por si mesmo, a partir de sua formação, de suas próprias "luzes", sendo que a imitação dos modelos antigos não deve ser servil ma conveniente aos interesses do presente. Em suma, conforme o texto documenta, no século XVIII, assiste-se à penetração da nova mentalidade iluminista na concepção da oratória sagrada e a uma rejeição dos métodos tradicionais.

33 As obras de oratória sagrada localizadas neste acervo são várias e merecem um estudo à parte.

34 SEBASTIÃO, De Sancto Antonio. Conversações Familiares Sobre A Eloquencia Do Pulpito onde segundo as doutrinas dos santos padres e melhores mestres se instrui em os principaes preceitos da oratoria cristã qualquer ecclesiastico que pretender ser perfeito ministro da palavra por hum religioso da Provincia De Santa Maria de Arrabida dada a luz por um amigo do autor. Lisboa: Manoel Manescal, Impressor do Santo Oficio, 1762.

35 "quando muito só podiam divertir a imaginação, mas de nenhum modo mover a vontade, e ferir os corações. A mesma experiência mostrou que aquelles discursos, ainda os mais bem fabricados, não erão mais que huns productos daquella faculdade, que só se estende aos objectos sensiveis e materiais. Pela imaginativa he que então se fazião as funções da razão e do bom sentido." (p.11-13)

36 Afirma também que o pregador deve possuir "conhecimento suficiente das leis, e dos costumes do paiz em que se vive" e dos "temperamentos dos povos", de "os costumes de cada condição, as differentes educações de cada estado, os prejuizos que dominam no presente século e o meio de persuadir e convencer os entendimentos e render os corações" (p.121). Por fim, o pregador deve ter um "perfeito conhecimento da natureza" (p.121) e um "vasto conhecimento de todas as coisas" (p.121) 
No caso do contexto luso-brasileiro, esta transformação de mentalidade é fortalecida também pela ingerência da política estatal na vida religiosa. No que diz respeito à formação dos padres e pregadores atuantes no Brasil, em meados do século XVIII, são exemplares os Estatutos da Universidade de Coimbra, ${ }^{37}$ de autoria pombalina. No capítulo segundo, dedicado à A Instrução Previa que devia ter o Estudante de Theologia, afirma-se que este deve ter conhecimento básicos acerca da retórica, mas também de filosofia, lógica, crítica e hermenêutica, ética não somente religiosa mas também social, visando "instrução científica nos dogmas da religião". Recomenda a prudência aos cristãos e aos pastores da igreja, em seus diferentes ofícios, inclusive no púlpito:

para que em lugar da Palavra divina e das maximas de huma sólida virtude,
e das práticas mais próprias, e conducentes para a reforma dos costumes e
emenda das vidas; que somente devem pregar, e ensinar aos fieis, não pre-
guem e ensinem aos povos doutrinas perigosas, erroneas, sediciosas, e con-
trarias a santidade da vida cristã e á paz da igreja e do estado e em vez de se
fazerem os christãos virtuosos, temerosos a Deos, obedientes à lgreja e aos
princípes soberanos; não lhes introduzam as sementes de uma falsa pieda-
de, nem os formem fanaticos, superstiziosos, hypocritas e rebeldes ao su-
premo poder espiritual e temporal, que todos provém igualmente de Deos
(cap. 4, folha 102, parágrafo 53).

Inclusive, com o objetivo de ensinar esta prudência, institui-se a disciplina Prudência cristã e pastoral, no terceiro ano do curso teológico.

Desse modo, se por um lado, ao longo do século XVIII, houve um esforço de regulamentação das formas e dos conteúdos da pregação pela hierarquia católica brasileira, por outro lado, o território da oratória sagrada, que vinha a ser melhor definido em conformidade à normas tridentinas, torna-se imediatamente o alvo de um conflito entre a Igreja e o Estado que, ao assumir uma pretensão absolutista, considera a pregação como campo próprio de ingerência, controle da população e transmissão ideológica. O terreno da formação dos pregadores e a discussão acerca das competências para tanto, é o terreno privilegiado desta confrontação. ${ }^{38}$

37 Estatutos Universidades De Coimbra Compilados Debaixo Da Immediata E Suprema Inspecção Del Rey D. José Primeiro Nosso Senhor Pela Junta Da Providencia Literararia Creada Pelo Mesmo Senhor Para A Restauração Das Sciencias E Das Artes Liberaes Nestes Reinos E Todos Seus Dominios Ultimamente Roborados Por Sua Magestade Na Sua Lei De 28 De Agosto Do Presente Ano. Lisboa: Regia Officina Typografica 1722, Livro I, Do Curso Theologico.

38 Um documento elucidador a este respeito é o Códice Costa Matoso. O códice é coleção de notícias dos primeiros descobrimentos das minas de América feitos pelo doutor Caetano da Costa Matoso, Ouvidor geral de Ouro Preto, de cujo cargo tomou posse em 1749 No documento, são fornecidas informações acerca da situação financeira do bispado, entre as quais informações acerca dos gastos com pregadores, cuja presença parece ter sido considerável na diocese. Os relatórios exigidos pelo ouvidor ao bispado visam o controle e a vigilância da administração régia sobre os recursos financeiros da igreja. Com efeito, a pretensão de Caetano da Costa Matoso em controlar as contas das irmandades mineiras e os rendimentos do bispado 


\section{Difusão da pregação no território brasileiro}

Visando evidenciar a importância da pregação na vida religiosa e social dos núcleos urbanos do Brasil colonial, mapeamos os principais centros de atividade e descrevemos os acontecimentos mais relevantes referentes a esta prática com base nos documentos dos contemporâneos (em muitos casos espectadores) e dos historiadores locais e a partir de um levantamento de sermões que realizamos em $2002^{39}$ e que fornecem a indicação da cidade onde foram proferidos. ${ }^{40}$

Salvador constitui-se no centro mais importante de difusão da oratória sagrada na Colônia, mas grande evidência assumem também as cidades pernambucanas. Curiosamente, apesar de grande parte dos sermões por nós localizados terem sido pregados em Salvador, os textos não mais se encontram em acervos desta cidade. Os motivos deste desaparecimentos são diversos, alguns antigos e outros recentes. Dentre os recentes, o descaso e a dificuldade no que diz respeito à preservação da documentação históricos nos arquivos das Igrejas e congregações religiosas locais; e dentre os antigos, a história política do Brasil e da Colônia, acarretando, ao longo dos séculos XVIII e XIX, a perseguição às ordens religiosas pelo Estado e a conseqüente confisca e dispersão do patrimônio histórico das mesmas. O fato de que nos demais centros urbanos relevantes da época, como Mariana e Rio de Janeiro, foram encontrados quantidades menores de sermões escritos, não significa porém que a atividade oratória tenha sido menor, mas apenas que o custo da transcrição e impressão dos textos pregados era muito alto para poder ser assumido pela população. Além disto, como nosso levantamento não incluía os sermões de padre Antônio Vieira, já bem conhecidos e reproduzidos inclusive em edição moderna, evidentemente não constaram nesta tabelas locais como São Luís de Maranhão, onde porém sabese que o famoso jesuíta pronunciara muitos importantes discursos. De qualquer forma, existem numerosas informações que pudemos obter pela pesquisa em arquivos e pela leitura de fontes de história local e que permitem reconstruir mesmo que se modo sumário e parcial, o panorama da pregação em algumas regiões mais significativas da realidade do Brasil colonial. Percorremos rapidamente este itinerário, quase uma "pe-

desembocaram num grave conflito entre o bispo e o ouvidor que finalmente levaram à destituição do mesmo. FIGUEIREDO, Luciano Raposo de Almeida e CAMPOS, Maria Verônica. (org) Códice Costa Matoso, coleção de notícias dos primeiros descobrimentos das Minas na América que fez o doutor Caetano da Costa Matoso sendo ouvidor geral das do outro preto, de que tomou posse em fevereiro de 1749, e vários papéis. Belo Horizonte: Fundação João Pinheiro, 1999, 2v. (Coleção Mineiriana).

39 Vide MASSIMI, Marina. O conhecimento de si na oratória sagrada no Brasil do século XVI ao século XIX: um estudo histórico. São Paulo: Fapesp, 2003 (Relatório Científico - mimeo).

40 Excluindo-se do levantamento as peças de oratória de Antônio Vieira, obtivemos os seguintes dados parciais: 69 sermões impressos que foram pregados na cidade de Salvador e redondezas, 8 no Rio de Janeiro, 32 em Olinda e Recife, 7 em Mariana e Vila Rica de Ouro Preto, 2 em São Paulo e 17 em outros centros menores da região de São Paulo e Espírito Santo. 
regrinação" pelos territórios onde a palavra sagrada ecoara na Terra de Santa Cruz.

Na região da Bahia, várias ordens religiosas atuaram na pregação, dentre eles jesuítas, beneditinos, carmelitas, mas posteriormente também capuchinhos e frades menores. No que diz respeito aos beneditinos, cuja primeira fundação em Salvador - a Ermida de São Sebastião - , remonta ao ano de 1582, relata a crônica interna do mosteiro, chamada O Dietario Das Vidas E Mortes Dos Monges, Que Falecerão Neste Mosteiro De São Sebastião Da Bahia Da Ordem Do Principe Dos Patriarchas S. Bento, Pasta 42541, copia do manuscrito elaborado de 1591 a 1815, que em breve tempo eles se deram a conhecer à população, entre outras coisas "pela freqüência dos púlpitos" (cit. p.45) e pelas missões junto às aldeias indígenas. ${ }^{42}$ Com efeito, as atividades dos monges beneditinos no Brasil, além do serviço liturgico, envolviam também a missão junto aos índios, ${ }^{43}$ conforme pregam suas primeiras Constituições:

Mandamos aos Prelados que são ou forem nas Partes do Brasil trabalhem com toda a diligencia que em todas as casas haja um Monge, ou mais se puder ser que saiba a língua da terra, para poder confessar e doutrinar a gente dela, pelo muito fruto espiritual que disso se espera, que haja nas ditas partes por ser esse nosso principal intento de salvar as almas dos tais (p.124).

Estas atividades terminam em 1764, quando o Marquês de Pombal proíbe a recepção de noviços nas corporações monásticas de Portugal e Brasil.

O Dietario, fornece notícias acerca das práticas de oratória sagrada e da biografia dos monges pregadores e cita um grande número de sermões pregados e escritos pelos monges de Salvador, parte dos quais porém não puderam ser localizados nos acervos sendo que provavelmente foram perdidos. As vicissitudes da vida dos pregadores beneditinos, são várias: há alguns que dedicam-se com afinco à pregação vindo

41 Sobre a natureza deste documento, explica Endres que "A constituição 3, n.-79 do livro 2 das nossas antigas constituições De Archivo Monasterium et congregationis determina que, em cada mosteiro haja um livro intitulado Dietario, dividido em duas partes, cuja primeira parte trate da fundação do mosteiro e de tudo o que nele acontecer digno de menção, dos prelados que o tem governado e o que tem feito mais digno de lembrança. Na Segunda parte se escreva a vida e morte dos Monges, que faleceram no respectivo cenóbio, os ornamentos de virtudes e exemplos, com as dignidades e honra com que estavam revestidos" LHOR, José Endres. A Ordem de São Bento no Brasil quando Província 1582-1827, Salvador: Edições do Mosteiro, 1980, p.3. Em Salvador, frei José de Santa Maria se encarregou de redigir as crônicas revendo no cartório do mosteiro os documentos para descobrir noticias sobre a fundação e sobre os primeiros monges. Elaborou o Dietario até o monge n.44. O segundo cronista a partir de 1728 foi Ruperto de Jesus, até 1746 . Em 1746 foi Bernardo da Encarnação, autor da biografia dos monges de 44 a 217. Outro cronista sucessivo foi Fr. Miguel Arcanjo da Anunciação, que continuou a crônica até o ano de 1763.

42 Em 1584, Gabriel Soares de Sousa, oficial da Câmara, fez doação ao mosteiro de seus terras, pedindo para ser sepultado com sua mulher na capela mor da Igreja de São Bento, de modo que com o crescimento, Mosteiro foi elevado a Abadia naquele mesmo ano.

43 Vide Capitulo Geral de 1575 do Mosteiro de Tibães; vide documento da Junta de Pombeiro de 22 a 26 de agosto de 1596, onde se redigiram as primeiras Constituições da Província do Brasil tratando do governo dela, capitulo 9. 
inclusive a falecer no período do preparo ou durante a execução do sermão; outros que, após uma brilhante carreira de pregadores, deixam a vida religiosa. Alguns pregadores são mais queridos pela população baiana, tais como o abade frei Manuel do Desterro (-m.1668), o qual "servio socorrido de uma perfeita voz, no púlpito aonde era ouvido com muita atenção pela boa aceitação com que pregava" (p.25).

No território de Pernambuco também, as atividades de pregação dos beneditinos são relevantes. Acerca do famoso pregador pernambucano Frei Ruperto de Jesus, o Dietário narra os efeitos taumaturgicos da palavra por ele pregada, capaz de constituir-se em remédio do corpo além de ser remédio da alma. De fato, estando frei Ruperto em Recife e "vendo esta cidade infestada com huma doença que o Diabo poz o nome de Caya, subindo ao pulpito declamou com tanto espirito e fervor que em breves tempos se vio extinta aquella peste de entre as creaturas" (p.61). Tais acontecimentos faziam com que a pregação se tornasse um acontecimento muito atrativo para a população da cidade que enchia as igrejas para ouvir as práticas. Todavia, a pregação não é apenas teatro de maravilhas mas também de disputas entre as diversas ordens religiosos presentes na cidade, conforme relata a crônica na mesma biografia de frei Ruperto:

Pregando em Santa Theresa no primeiro dia de sua Igreja nova, dando-se por offendido hum Religioso do Carmo do muito que ouvio exagerar as virtudes da reforma, no dia seguinte subindo ao pulpito intentou deslustra-lo com alguns imprudentes dicterios; mas com confusão sua por que todos conhecerão que aquelles ditos erão effeitos de inveja que não podia eclipsar (digo) de inveja de hum resplandor que não podia eclipsar (p. 61).

A crônica relata que nos ouvintes, a pregação suscitava muitos "affectos" (p.106), ao ponto que em alguns caso, como ocorreu com Frei Plácido de Santa Anna, que quando pregava em Pernambuco, "as Domingas de quaresma nesta nossa igreja, concorria tanto o povo que era necessário porem-se guardas nas portas para evitar algumas desordens, que podiao acontecer" (p.128). O movimento dos afetos e o consenso dos ouvintes, porém, não eram fins para si mesmos, mas destinados à reforma dos costumes e à pacificação das relações sociais, não apenas nas áreas urbanas mas também no sertão.

Dentre os centros urbanos mineiros, Sabará destaca-se no que diz respeito à vida religiosa. Segundo observa Ávila ${ }^{44}$ e como podemos verificar em nosso levantamento junto aos acervos locais, durante as cele-

44 Ávila observa que do fato dos sermões terem sido pregados naquela cidade, "se depreende que a vida religiosa em Sabará, no decurso do século XVIII, nada ficava a dever, no cuidado devoto ou na exterioridade ritual, à das outras principais vilas mineiras, excepção talvez de Mariana". AVILA, A. O lúdico e as projeções do mundo barroco, São Paulo: Perspectiva, 1994, p.226. 
brações a prática do sermão é comum e documentada nos arquivos. Conforme as anotações dos Livros de Termos das Irmandades sabarenses, houve vários sermonistas que atuaram nas solenidades ao longo do século XVIII. Todavia, na maioria dos casos, pouquíssimos textos escritos destas peças de oratória sagrada puderam ser localizadas. ${ }^{45}$

Se é difícil obter notícias acerca do conteúdo das pregações em Sabará, os registros dos movimentos financeiros das Irmandades dão porém ampla e detalhada notícia dos custos dos sermões. Com base em pesquisas desenvolvidas sobre tais documentos, Ávila relata que na referida ocasião, "pelos sermões pronunciados nesta festa de fausto marcadamente barroco, receberam os dois oradores, respectivamente, 32 e 20 oitavas". 46 Em documentos da Irmandade do Carmo — Livros dos Termos escritos pelo padre frei Manuel José de Jesus Maria — são colocadas as regras da irmandade e são registrados todos os atos da vida litúrgica e os gastos decorrentes da mesma. Vários itens referem-se ao assunto da pregação. No Livro do Termos de 9 de setembro de 1767, por exemplo, afirma-se que o tesoureiro pagou "ao pregador de manhã da nossa função trinta e duas oitavas e da tarde vinte oitavas" (p.30), pagamento este que se refere aos dois sermões do dia da transladação da imagem de Nossa Senhora do Carmo da Matriz para a sua capela. Termos análogos encontram-se nos livros de outras irmandades da cidade.

Outro grande centro religioso das Minas do século XVIII é a cidade de Mariana, sede episcopal. O texto Áureo Trono Episcopa ${ }^{47}$ contém o relato da festa da posse do primeiro Bispo de Mariana e dois sermões de José de Andrada e Moraes. Neste documento e nos sermões citados, é descrita e explicada em seu significado alegórico, a procissão triunfal da entrada do prelado ocorrida no dia 28 de novembro de 1748. Se no caso da procissão descrita no documento de Sabará, a própria representação sagrada constitui-se num grande "discurso" alegórico, no texto dos sermões proferidos, acontece o processo inverso, no sentido de que a representação é traduzida em palavras e assim transmitida aos ouvintes pelo pregador, de modo que os ouvintes possam de alguma forma "visualiza-la" pelos "olhos" espirituais.

45 Ávila transcreveu dois destes sermões pregados nas exéquias de personalidades eminentes ligadas à história política e religiosa da Capitania, em 1741 e 1784. Trata-se do sermão de Manoel Freire Batalha contendo o elogio fúnebre do bispo Antônio de Guadalupe de 1741 e o de Luís Vieira da Silva, lente de filosofia do Seminário de Mariana, o ideólogo da Inconfidência mineira, sermão pronunciado em 1784 por ocasião da morte do aludido padre Loureço José de Queiroz Coimbra.

46 Oitava: antiga medida de peso correspondente a 3,580 gramas.

47 Oração acadêmica e congratulátoria á felicissima e desejada entrada do excelentíssimo e reverendíssimo bispo do bispo do Bispado de Mariana, feita publica e solemnissimamente na sua capital a 28 de novembro de 1748. Foi presidente da academia e recitou a mesma oração como remate de todos os applausos que se fizeram a sua excelência reverendíssima o m.r. reverendo doutor José de Andrade e Moraes, novamente creado arcipreste da cathedral do dito bispado. Esta função acadêmica se fez a 10 de dezembro do ditto anno e assistirão a ella o dito excelentíssimo reverendíssimo senhor, com toda a nobreza da mesma cidade. Em: Revista do Arquivo Público Mineiro, n.VI, 1902, fasc.1, p.379 a 491. 
Em Ouro Preto ${ }^{48}$ existe um registro das práticas de pregação realizadas na ocasião da soleníssima procissão do Triunfo Eucarístico em $1730^{49}$ relatada na crônica do português Simão Machado, ${ }^{50}$ procissão esta que levava o Santíssimo Sacramento da Igreja de Nossa Senhora do Rosário para a Igreja Matriz do Pilar, recentemente restaurada. Machado narra que, após a instalação do Sacramento em seu Trono e após celebração da Missa cantada com musica e dois coros, foram pregados diversos sermões, dos quais, infelizmente não foi achado o texto impresso.

Que as atividades no campo da oratória sagrada também em Ouro Preto fossem freqüentes, é documentado pelas informações colhidas nos Livros de Termos e Deliberações do Arquivo da Paróquia da Nossa Senhora do Pilar. Nos livros referentes ao período de 1780 a 1861, ${ }^{51}$ encontramos diversos Termos de Ajuste elaborados no fim do século XVIII sobre pregação. No Arquivo constam documentos parecidos atestando a presença do sermão durante os referidos períodos litúrgicos da Quaresma e da festa do Bom Jesus em diversos anos do século XVIII. ${ }^{52}$ Uma nota um tanto irônica acerca da pregação em Vila Rica no século XVIII, é oferecida por um texto literário, as Cartas Chilenas de Antônio Gonzaga, ${ }^{53}$ o qual retrata, de forma satírica, o pregador que integra o cortejo da entrada do Fanfarrão Minesio, em Vila Rica.

Outro centro mineiro muito significativo no que diz respeito à história da pregação é a cidade de São João del Rey, criada em 1713. Que a pregação marcou a vida religiosa e social de São João del Rey desde as origens, é atestado por um documento intitulado 54 "narrativa da descoberta do ouro em São João del Rey em 1704, as hostilidades e disputas entre paulistas e reinois, os combates de 1709". O documento, de autoria de José Alvares de Oliveira, morador de São João del Rey (1750), ao narrar a origem do Arraial Novo do Rio das Mortes, hoje São João del Rey e a edificação da Igreja Matriz dedicada a Nossa Senhora do Pilar, faz referência ao pregador Mathias Salgado, ${ }^{55}$ que ali atuara, bem como

48 Em LIMA, A.J. Vila Rica De Ouro Preto. Belo Horizonte: Edição Autor, 1957.

49 Revista do Arquivo Público Mineiro, Belo Horizonte, n.4, p.985 a 1016, 1989

50 MACHADO, S. F. Triunfo Eucarístico, exemplar da christandade lusitana em pública exaltação da fé na solene transladação do Diviníssimo Sacramento da Igreja da Senhora do Rosário para hum novo templo as Senhora do Pilar em Villa Rica, corte da Capitania de Minas aos 24 de mayo de 1733. Lisboa, Officina da Música, 1734. Publicado em: ÁVILA, Afonso. Resíduos Seiscentistas em Minas. Belo Horizonte: UFMG, Centro de Estudos Mineiros, 1967, v.1.

51 vol. 0397, Rolo 102

52 Termo por onde se determina Quatro Sermões nas Quatro Domingas da Quaresma e Dois na procissão de Passos e um na festa do mesmo Senhor no dia 3 de mayo de 17 de dezembro de 1786 (Idem, folha 6).

53 GONZAGA. Cartas chilenas. Lisboa: Liv. Martins ed., 1944.

54 FIGUEIREDO, Luciano Raposo de Almeida e CAMPOS, Maria Verônica. (org) História do distrito do Rio das Mortes, sua descrição. descobrimento das suas minas, casos nele acontecidos entre paulistas e emboabas ereção de suas vilas. In: Códice Costa Matoso. V.1, p.270 a 293.

55 MACHADO, Diogo Barbosa. Bibliotheca Lusitana. 2.ed. Lisboa: Bertrand, 1930-35, v.2, p.680. Os editores do Códice também fornecem uma Noticia Biográfica sobre Salgado (em vol. 1, p. 58), cujos sermões em parte localizamos: Natural de Lisboa. Ingressou na Companhia de Jesus em 1716. Doutorou-se em Direito Canônico. O bispo dom frei Manoel da Cruz opôs-se ao seu provimento ao cargo de vigário da matriz de São 
a dois púlpitos que ainda hoje podem ser admirados na mesma (em: Códice Costa Mattoso, vol. 1, folhas 98v e 99).

Notícias acerca da atividades de oratória sagrada em São João podem ser colhidas junto ao Museu Regional de São João del Rey. ${ }^{56}$ Os documentos encontrados relatam as muitas e importantes festas que foram realizadas em São João del Rey no século XVIII, sendo a maioria delas ocasiões para a ocorrência das pregações. ${ }^{57} \mathrm{O}$ livro de Compromisso Da Veneravel Ordem Terceira Do Monte Do Carmo, Da Cidade De São Joao Del Rey, de 1727, contém no capítulo trigésimo segundo, Dos Passos Da Sexta Feira De Quaresma E Sermões Da Ordem, algumas interessantes dicas acerca do controle, pela irmandade, da qualidade das pregações, para que nas ocasiões estabelecidas pelo ritual para o desenvolvimento desta atividade, à "grande devoção e piedade com que a nossa venerável Ordem Terceira do Carmo faz nas tardes da sexta feira de quaresma, a memória dos Passos da Sagrada Paixão de Cristo Senhor nosso", corresponda uma ponderada escolha de pregadores que cumpram a "observância dos estilos até aqui praticados", "a fim de se não desgostarem os nosso irmãos zelosos" e também "pello credito de nossa religião nas ditas sextas feiras, em que concorre a maior parte desta cidade". A ênfase do documento na necessidade de contratar um "bom Pregador" e de escolher os pregadores "a tempo, para que estes se não possam escusar, allegando que tem já outros sermões" (fl.176v), parece ser o indício de uma certa dificuldade em realizar estas condições ideais, já que é "por experiência" que justifica-se a pertinência destas disposições.

O primeiro pregador de destaque na região de São Paulo foi o próprio José de Anchieta ${ }^{58}$. O biografo de Anchieta, a ele contemporâneo, Quirício Caxa, ${ }^{59}$ ao enaltecer o grande conhecimento que este tinha da

João del Rey. Autor do Monumento de agradecimento tributo da veneração, obelisco funeral de obséquio, relação fiel das reais exéquias que à defunta Majestade do fidelíssimo e augustissimo rey. (Lisboa, Oficina de Francisco da Silva, 1751).

56 GUIMARÃES, Geraldo. São João Del Rey Século XVIII. História Sumária. São João del Rey: Edição do Autor, 1996.; ALVARENGA, Luís De Melo. Catedral Basílica de Nossa Senhora do Pilar. São João Del Rei: Instituto Histórico Geográfico de São João Del Rey, 1971.; VIEGAS, Augusto. Noticia De São João Del Rey. Belo Horizonte, 1953.; CINTRA, S. O. Efemérides de São João Del Rey. Belo Horizonte: Imprensa Oficial de Minas Gerais, 1982

57 Edital do 11 de fevereiro de 1781 da Mesa da ordem de São Francisco, da normas para a procissão da quarta feira de cinzas, em Efemérides, vol. 1, p. 70. No livro de Compromisso da Irmandade Da Boa Morte, de 1786, no capitulo decimo dedicado às festividades de Nossa Senhora, a associação compromete-se em realizar duas festas de Nossa Senhora: uma no dia 14 de agosto, quando os irmãos "celebrarão o seu feliz transito com Missa cantada no Altar da Senhora e sermão" e no dia 15 de agosto, na ocasião da festa da Assunção, havendo neste caso também procissão e pregação, à presença do Santíssimo Sacramento exposto. Em ambas as circunstâncias, os atos litúrgicos deverão acontecer na presença da imagem sagrada, no primeiro caso "estando a Nossa Senhora morta no seu esquife" e a seguir quando, "recolhendo-se a Procissão, será a mesma Senhora tirada do esquife pelos sacerdotes, e depositada no túmulo, que estará no seu altar"; e no segundo caso saindo a imagem da "Senhora da Assumpção no seo Andor conduzido pelos Irmãos com a mayor solemnidade e pompa que puder ser." (5v)

58 Notícias acerca das informações referentes à pregação de Anchieta fornecidas pelos contemporâneos, são relatadas Vida do Padre José de Anchieta da Companhia de Jesus. 2ª.ed. São Paulo: Loyola, 1978.

59 ANCHIETA Joseph. Breve Relação. Rio de Janeiro: M.E.S., 1946. 
Sagrada Escritura afirma que "a trazia freqüentemente em suas pregações e mui a propósito, por ter felicíssima memória." (p.23, citado em Viotti, 1987, p.8); e que "era devotissimo do Santíssimo Sacramento, o que Ihe fazia ser mui assinalado no Sermão do Mandato" (ibidem), sendo que recolhia o aplauso popular "pela muita cópia de conceitos subidos e delicados" (Idem, p.9). Na biografia de outro contemporâneo, o Provincial Pero Rodrigues, ${ }^{60}$ narra-se acerca de Anchieta que "ouvindoo um dia pregar uma mulher simples, com muita devoção usou desta semelhança: o Espírito Santo põe na boca do padre o que há de dizer, assim como a pomba na boca do filho o que há de comer." (em Viotti, 1987 , p.9). Dentre os depoimentos fornecidos para o processo de canonização do missionário jesuíta, ${ }^{61}$ vários referem-se as suas atividades de pregação, destinadas "assim aos brancos como aos naturais da terra", "pelo português, como pela língua do gentio". A pregação de Anchieta era acompanhada por um intenso envolvimento dos ouvintes, "fazendo cantigas ao divino, que os meninos e as moças cantavam pelas ruas". ${ }^{6}$

Outro grande pregador jesuíta na região de São Paulo, foi Belchior da Pontes, ${ }^{63}$ nascido em Pirajuçara (SP) e atuante junto ao Colégio de São Paulo (1644-1719), exercendo suas missões de pregador em Paraguá e Curitiba e no interior de São Paulo. Ao descrever a capacidade por ele possuída de usar a palavra e a eficácia de suas pregações, um biografo contemporâneo afirma:

\begin{abstract}
Ajudava muito ao seu zelo a natural eloquência da língua Brazilica, de que era dotado; porque penetrando os desenganos do coração com a mesma efficacia, com que a propriedade da lingua feria os ouvidos, erão muito mayores os fructos, que tirava das suas practicas: pois tem a lingua nativa, armada de hum fervoroso espirito, mayor efficacia, para que, rendidas as vontades, acreditem, e sigão os ouvintes o que se lhes ensina (p.104).
\end{abstract}

Na cidade do Rio de Janeiro, a pregação é realizada pelos membros de diversas ordens religiosas, dentre eles os jesuítas, os frades menores, os capuchinhos, os beneditinos, os carmelitas. Na intensa vida religiosa carioca, ${ }^{64}$ ocorriam dois tipos de cerimonias ocorriam: eventos jubilosos

60 RODRIGUES Pero. Vida de Padre José de Anchieta da Companhia de Jesus. 2ª.ed. São Paulo: Loyola, 1978, p. 82.

61 Processo informativo da Bahia: Archivo Segreto Vaticano, Congregação dos Ritos, 303, 180-190v: citado por VIOTTI, H. (Org.) P. Joseph de Anchieta, S.J., Sermões. São Paulo: Edições Loyola, 1987, p.9.

62 O Processo Informativo reporta os depoimentos de testemunhas presenciais de alguns seculares, por exemplo a declaração fornecida a 3 de outubro de 1602, por Pedro Costa, de Rio de Janeiro: "Padre José tinha especial graça do Senhor para pregar e falar nas coisas de Deus, fazendo as suas pregações muito fruto nas almas, provocando os homens, assim com os seus sermões, como com suas admoestações secretas, a se afastarem de seus pecados e viverem bem" (em Archivo Segreto Vaticano, Congregação dos Ritos 302, 69v70, citado por VIOTTI, 1987, p.9-10).

63 Vida Do Venerável Padre Belchior De Pontes Da Companhia De Jesus Da Província Do Brasil Composta Pelo Padre Manoel da Fonseca Da Mesma Companhia E Província E, Offerecida Ao Nobilíssimo Senhor Manoel Mendes De Almeida, Capitão Mor Da Cidade De São Paulo. Lisboa: Of. Francisco Da Silva 1752, Reeditada pela Companhia Melhoramentos.

64 CAVALCANTI, N. O Rio de Janeiro Setecentista. Rio de Janeiro: Zahar, 2003. 
e eventos de dor. As celebrações do primeiro tipo incluíam as festas oficias permanentes e eventuais, sendo que as festas obrigatórias eram a de São Sebastião, de Santa Isabel, do Corpo de Deus e do Anjo Custódio - todas com procissão - e as eventuais eram as festas reais (nascimento, casamento, coroação). Normalmente, costumava haver pregação nestas ocasiões. Um documento das despesas realizadas em 1795 pela Câmara dos Vereadores na ocasião do nascimento do príncipe do Antônio, relata que a gratificação do pregador do sermão, Padre Mestre Basto de São Bento, foi de $38 \$ 400$.

\section{Conclusão}

O percurso aqui traçado aponta para evidências claras da importância, da freqüência e do grande alcance das atividades da pregação no contexto do Brasil do século XVI ao século XVIII. Essas atividades, não somente são voltadas para a catequese e a doutrinação dos ouvintes mas visam também uma reforma dos costumes abrangente toda a realidade pessoal, social e política dos emissores e dos destinatários. 